\title{
A Comparative Analysis of Productivity Improvement Techniques in Educational Institution of Holy Cross College
}

\author{
Engr. John Vincent L. Santos ${ }^{1} \&$ Joefil C. Jocson ${ }^{2}$
}

\author{
${ }^{1}$ Education Program, College Department, Holy Cross College, Sta. Rosa, NE, Inc., Philippines \\ ${ }^{2}$ Department of Engineering Management, Graduate School, Nueva Ecija University of Science \\ and Technology, Philippines \\ Correspondence: Engr. John Vincent L. Santos, Holy Cross College, Sta. Rosa, NE, Inc., \\ Philippines. \\ Email: j.vince103@gmail.com
}

DOI: $10.53103 /$ cjess.v1i1.2

\begin{abstract}
Abstract: This study aims to explore and evaluate productivity improvement techniques that have a significant impact on the performance of faculty employees at Holy Cross College's Education Institution. The considered techniques are named as follows: Technology-based, Employee-Based, Material-Based, Process-Based, Product-Based, and Task-Based. Participants include Holy Cross College's teaching personnel. This study utilized an online survey with questionnaire that aims to identify the level of provision and level of importance of each productivity improvement techniques. The collected data were organized and used Related-Samples Friedman's Two-Way Analysis of Variance by Ranks to evaluate the rank-ordered data set productivity improvement techniques premised on common criteria of faculty assigned roles. Additionally, Paired Sample Statistics, Correlation and Test were conducted to find out the relationship of productivity improvement techniques' level of provision and importance. The findings and recommendations for the possible integration of productivity enhancement techniques that should be highlighted and maintained in educational institutions were given. Results showed that the task-based approach is the most commonly utilized and preferred productivity improvement technique among teachers. While the technology-based strategy has the highest correlation in this pandemic period.
\end{abstract}

Keywords: Enhancing Productivity, Improving Efficiency, Boosting Performance, Organizational Commitment

\section{Introduction}

In today's dynamic and quickly changing workplace and worldwide economy, the development of personal performance, skills, knowledge, and experience of the workforce is an important factor for the growth of organizational performance (Yoshifumi, Sammogram, \& Manzuma, 2017). These personal developments have been challenged by 
the present epidemic. The staff has switched to other techniques and activities to sustain performance satisfaction. The educational sector is one of the areas that aim to preserve this satisfaction. The epidemic leads to the advocacy of distance learning programs. The usage of digital technology is advocated for both instructors and pupils. New learning methods, such as online classes, are given to complement academic education. As teachers and students adapt to new developments, they need to be assessed and supported properly (Pokhrel \& Chhetri, 2021). Management and administration of an organization may offer workers help so that they may make use of their talents and skills to grow and utilize their capabilities. Although management approaches range in education, this variation is seen as both a chance and a challenge to obtain a competitive edge via the better organization. (Yoshifumi, Sammogram, \& Manzuma, 2017).

Productivity is a popular summary metric for overall organizational performance in sectors and the economy as a whole. The basic concept is that an organization learns to generate more products with the same amount of inputs over time. In reality, the increased production from resources is what makes a profit. Productivity growth results in improved organizational performance (Hanushek \& Ettema, 2017). One big issue with productivity is that it means different things to different individuals. Productivity, according to the European Productivity Agency (EPA), is "a state of mind." (Boel, 2003). If productivity is linked to education, it refers to the growth of components in the teaching-learning process. Instruction, facilities, curriculum, research, extension, and training for the improvement of organizational performance are all included. Productivity demonstrates that instructors can constantly and regularly perform better. Incorporating new techniques and procedures into teaching is a continual undertaking (Boel, 2003).

The following concerns are explicitly addressed in this study:

a. What is/are the most utilized Productivity Improvement Technique/s in the Educational Institution of Holy Cross College?

b. What is/are the most preferred Productivity Improvement Techniques in the Educational Institution of Holy Cross College?

c. Does the preference of each employee matches the utilized productivity improvement techniques?

d. What are the specific provisions that must be adopted in order to enhance employee productivity in executing assigned tasks?

\section{Literature Review}

Every successful organization relies on a productive workforce. Having a team of hardworking, productive employees will make it much easier to meet the goals and objectives. An unproductive workforce, on the other hand, will make it hard to do anything. Several things influence the employees' productivity levels. Productivity is essential in educational institutions on many levels. On one level, it is about realizing individual faculty 
potential and achieving personal achievement. (De Lorenzo, Johnson, \& Dykes, 2011). Other levels may have a wide range of components. There are numerous significant ideas associated with achieving the needed employee productivity in an organization.

According to the goal-setting theory, when precise goals or objectives that are tough to accomplish are established in an organization, it naturally leads to high levels of employee productivity since the employee works harder to fulfill the set targets (Lunenburg, 2011). It should be emphasized, however, that when left alone, it does not result in greater production. It necessitates the dedication of others and teamwork. Work goals that are well stated are excellent for increasing productivity since they are measurements of productivity (Author, G. 2019, October 24). The simpler and efficient the target goals are, the employees are more motivated to accomplish them.

The system theory, which contends that an organization is made up of distinct parts within its structures, is another theory that supports the notion of employee productivity (Mason, R. O. 1979). If the organization wants to improve its performance, the various systems inside the organization must have the same vision. To increase employee productivity, the systems must correctly recognize employee capacity and function in tandem with one another. It means that each subsystem must function well to improve employee productivity. If one employee's performance falls short of expectations, he has an impact on the entire subsystem. These subsystems must be capable of supporting employee growth by providing appropriate resources that they may use in their given tasks.

The concept of employee wellness relates to the emotional and physical well-being of an employee. In addition, the training of employees has a major impact on how well equipped they are for their work. If better equipped, they will be more productive. Employee-centered methods assist to strengthen and grow the skills and passion of workers for work. ("5 Critical Factors Affecting Employee Productivity At Work", 2019). Teacher development programs are vital tools to ensure that the knowledge, skills, and attitudes of teachers continue to increase in response to changes in educational systems and social expectations.

One aspect of a teacher development program can be traced from the utilization of technology. Technological transformation is needed to achieve substantial productivity to increase fundamental structural changes. Technology is used to assist both teaching and learning by infusing classrooms with digital learning resources such as computers and handheld devices, increasing student engagement and motivation, and accelerating learning. Technology serves as a platform for productivity, especially in times of a pandemic. Materials are another important resource in education. The appropriate and just resources for educational institutions and programs should be available to all students and faculty members through books, additional training materials, open educational resources, and technology that are non-discriminatory, that is friendly, context-specific, costeffective, and accessible to all. 
Finally, the organization theory states that the organization, which shape the attitudes and the conduct of its employees, must alter all its structures in the right sequence to achieve its primary aim of improving production (Hilgert, 1964). The method of organizational management substantially influences employee productivity. One approach that the management provides that impacts a faculty's productivity is the environment in which they work. An individual's work environment influences their mood, drive, and overall success in the company. The location of an employee's workplace has an impact on how the work process is carried out. When the working environment is proved to be more enjoyable and safe, it attracts more personnel. Process adoption, in addition to a secure and comfortable workplace, is one of the most successful ways for increasing team productivity. A process is a detailed sequence of steps for carrying out a certain task. Thus, one factor to consider in improving productivity is the process and the needed inputs in the process such as simplified activities and a safe environment (Santos, \& Gallardo, 2021).

Variables affecting the tasks are one of the most significant elements for improving productivity. Tasks that encourage, motivate and reward. The management shows to employees they do a wonderful job and they criticize constructively. Above all, give personal incentives to execute the task properly. The management should openly show one employee's achievement for other employees to encourage others to feel satisfied. Increased productivity is likely to be high on its to-do list if management motivates people to work more and earn incentives (Bisson, 2021).

\section{Productivity Improvement Techniques}

The aim of this study is to detect the most commonly used strategy for improving productivity and its significance for faculty members. This will help management to identify which techniques should be emphasized to further improve corporate performance. Three productivity theories were studied to identify the necessary strategies of increase in productivity. To summarize the three theories of productivity that are discussed, the Goal-setting theory implies that the approach to product-oriented productivity has to be improved. The system theory emphasizes the requirement for the employee development, technology and materials that increase productivity. Finally, the theory of organizations says that a process and tasks are necessary for acceptable techniques for improving productivity. Figure 1 shows the productivity theories with connection to the techniques for improvement of productivity considered. 


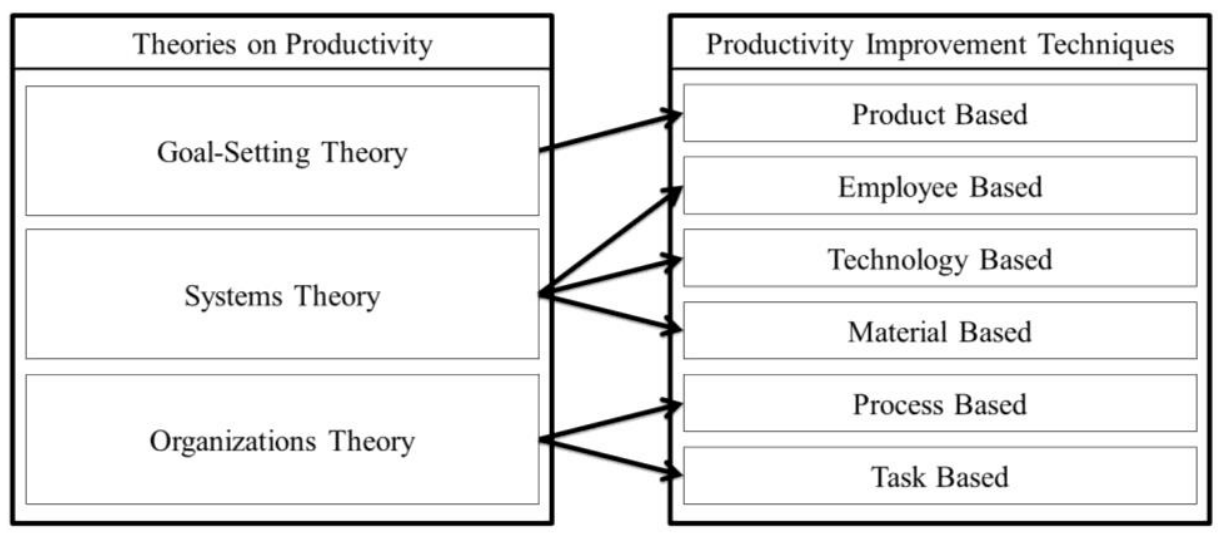

Figure 1: Productivity theories and improvement techniques

The study evaluated the preferred techniques to be utilized by workers since they will be impacted and benefited in terms of performance and personal development. Furthermore, the research will aid in the dissemination of information and the increasing awareness of productivity enhancement techniques used in the teaching-learning process. The topic of this study focuses on productivity improvement techniques used at Holy Cross College, an educational institution. The following are the considered productivity improvement techniques:

\section{Technology-Based}

The usage of technology is referred to be increasing productivity in educational elements. For instance, technology is used to better teaching and learning process, such as learning management systems, internet connectivity, and accessible software that makes teachers' jobs easier and more efficient. This Productivity Improvement Technique relates to academe work-related technologies, such as:

- Online Management Systems

- Computers and Internet

- Availability of Software and Applications

\section{Employee-Based}

Financial and non-financial incentives at the individual and group levels, employee advancement, job expansion, job enrichment, and worker engagement in decision-making are all part of this productivity development approach. This productivity development approach expresses appreciation to employees which motivates them to seek and sustain their success. This Productivity Improvement Technique refers to provisions 
that encourage staff growth and development, such as:

- Financial and non-financial incentives

- Employee promotion

- Improved job design, job enlargement, job enrichment

\section{Material-Based}

This approach of increasing productivity entails providing instructors with the required practical academic materials. Materials include textbooks, manuals, electronic interactive devices such as computers, and office equipment. Even if there has been a shift toward online learning in education, instructors continue to do administrative work with the help of these tools. This might also contain school and office materials. This Productivity Improvement Technique relates to the academic supplies that are required, such as:

- Quality Reading and Reference Materials

- Electronic Interactive such as Computer Accessories

- Classroom and Office Supplies

\section{Process-Based}

In school, the process is how students learn. Pedagogy, teaching and learning approaches, philosophies, classroom management, and a safe learning environment all have an impact on learning styles. This productivity enhancement approach refers to the practices that management permits or gives in order to help instructors feel more at ease and excited about their job processes. This Productivity Improvement Technique refers to provisions that aid in the improvement of the working process, such as:

- Work Simplification and Freedom

- Safe and Comfortable Working Environment

- Alternative work arrangements

\section{Product-Based}

This productivity development approach refers to what the school hopes to achieve. Employees may be more motivated to perform their work if they understand what the expected consequences of their employment are. The simpler and more efficient the desired outcomes are, the more motivated people are to achieve them. This might contain realistic criteria as well as output requirements. This Productivity Improvement Technique relates to target work results such as:

- Feasible Standards 
- Simplified Output Requirements

- Objectives, Mission and Vision

\section{Task-Based}

This method to increase productivity combines managerial style, organizational communication, work culture, and workplace motivation. Organizations must be able to develop skills in terms of the desired task organization and strengthen them via efficient management, which will result in the accomplishment of goals by providing it. This Productivity Improvement Technique is used for elements that influence work performance, such as:

- Effective management style

- Positive work culture

- Motivation from the superiors

Methodology 


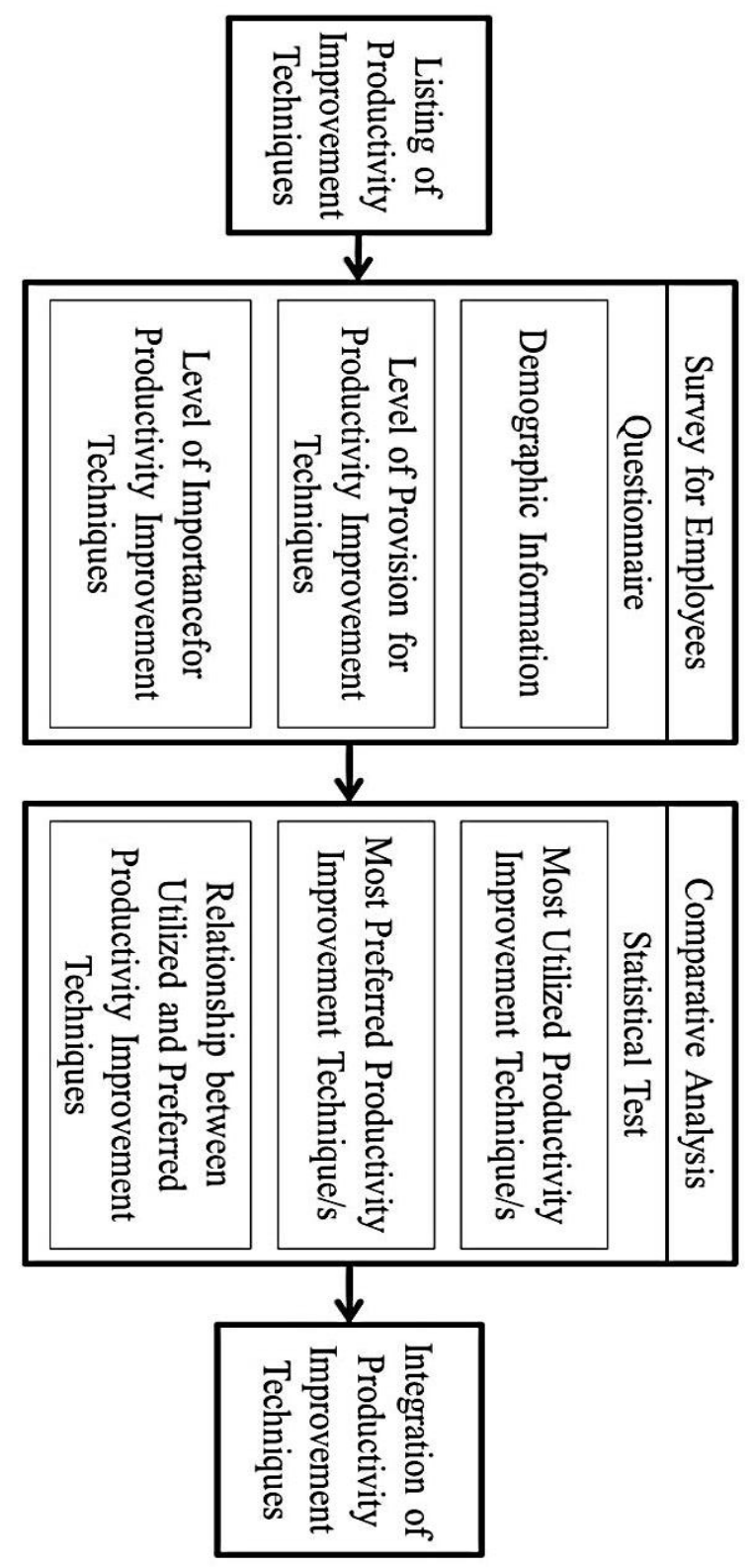

Figure 2: Methodology of the study 
The methodology depicts the steps used in this study to reach the conclusion and solutions to the research challenges. This study's methods is broken into four phases. These phases are as follows: Listing of Productivity Improvement Techniques, Survey for Employees, Comparative Analysis and Integration of Productivity Improvement Techniques.

\section{Listing of Productivity Improvement Techniques}

The first step is to make a list of all conceivable Productivity Improvement Techniques. The researcher considered six (6) Productivity Improvement Techniques, namely: Technology-based, Employee-Based, Material-Based, Process-Based, ProductBased, and Task-Based.

\section{Survey for Employees}

The second stage is to design and assess the use of productivity improvement techniques using a questionnaire distributed to respondents. The survey's objective is to determine which is the most widely used based on which generates the most assistance for employees in the educational sector. Furthermore, the study attempts to establish which productivity improvement technique is the most favored based on the demands and relevance to the organizational performance of the faculty employees of the educational institution of Holy Cross College.

The researcher used a questionnaire survey for the collection of data. The questionnaire included the parts, namely: demographic information, level of provision for productivity improvement techniques and finally the level of importance for productivity improvement techniques. The researcher acquired the necessary data for quantitative and qualitative comparisons of the productivity improvement techniques by taking notes on the observable elements and assessing the criteria. The collected data were ranked in nature and was analyzed using SPSS. In addition, the researcher gathered extra relevant material from publications on the internet and other scientific journals, both published and unpublished.

\section{Comparative Analysis}

The comparative analysis is strongly weighted in statistical findings. Statistical tests are necessary to make inferences for the population from the sample taken. In this study, six (6) productivity improvement techniques were compared as to what is the most utilized and most preferred based on the responses of the sample. Additionally, the most 
utilized is also compared with the preferred approaches of the faculty employees in improving productivity. A rank-ordered data set requires a nonparametric statistical treatment. With the samples identified as multiple dependent, a Related-Samples Friedman's Two-Way Analysis of Variance by Ranks is conducted. Additionally, Paired Sample Statistics, Correlation and Test were conducted to find out the relationship of productivity improvement techniques' level of provision and importance.

\section{Integration of Productivity Improvement Techniques}

The comparative research was carried out in order to give findings and recommendations for the future integration of productivity enhancement methods. These recommendations highlight the significance of using productivity development strategies to assist instructors in successfully facilitating instruction, improving productivity in other areas of education, and improving organizational efficiency. Realizing the level of provision and preference for each productivity improvement technique among employees will assist management in determining which techniques should be integrated to meet the needs and address the concerns of faculty assigned roles in instruction, research, training, extension, and other assigned works.

\section{Results}

The questionnaire was distributed individually to Holy Cross College faculty employees using an online form in order to collect survey results. The questionnaire survey was divided into two sections. The first section collects data for the provision of each productivity improvement technique, with each employee rating each productivity improvement technique on three levels: Poor Provision (1), Satisfactory Provision (2) and Excellent Provision (3). The second section collects data on the importance of each productivity development strategy, and employees must also rate their degree of preference: Unimportant (1), Important Enough (2) and Very Important (3).

Both sections are based on the duties of each faculty member, which are as follows: Facilitating Instruction, Other Assigned Work (Such as Accreditations), Conducting Research, Pursuing Professional Development, and Participating in Extension Programs. All of these characteristics are assigned to each faculty member as roles, and respondents are asked to rate the amount of provision and importance of productivity improvement techniques for these roles.

The results presented are summaries of the tests performed, which are as follows: Related-Samples Friedman's Two-Way Analysis of Variance by Ranks for the Most Utilized and Most Preferred Productivity Improvement Technique, and Paired Sample Ttest for the Relationship between the Utilized and Preferred Productivity Improvement 
Technique.

\section{Most Utilized Productivity Improvement Technique}

Based on Table 1, the result of the statistical tests applied states that there is a significant difference between the six (6) productivity improvement techniques' level of provision premised on the roles of the faculty employees.

Table 1: Hypothesis test summary for most utilized productivity improvement

techniques

Hypothesis test summary

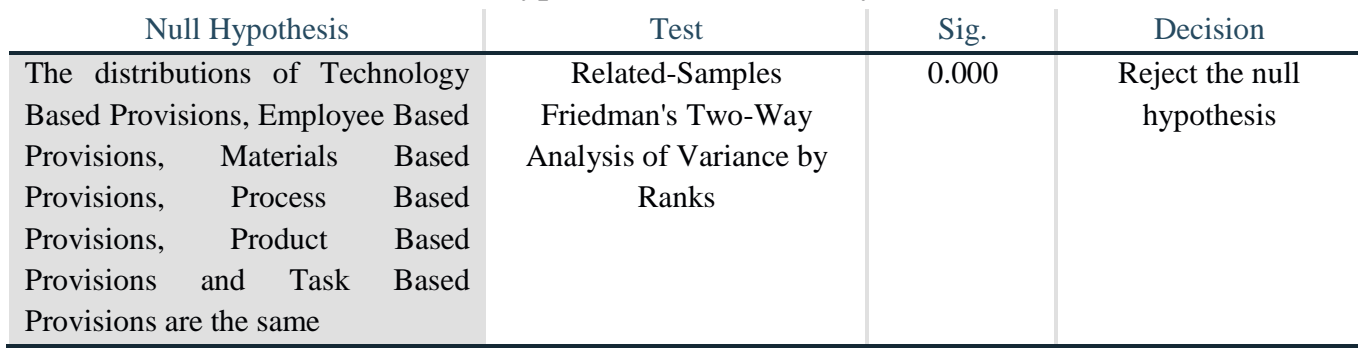

Based on the mean ranks, Figure 3 shows that most utilized and significantly provided productivity improvement technique is Task-Based (Mean Rank $=3.81$ ), followed by Process-Based (Mean Rank = 3.75), Employee-Based (Mean Rank = 3.68), Technology-Based (Mean Rank = 3.47), Product-Based (Mean Rank = 3.21), and lastly, Materials-Based (Mean Rank $=3.08$ ). This result implies motivations and encouragement in working with tasks are the most commonly utilized form of productivity improvement technique. While materialized provisions such as feasible outputs, classroom and office supplies, and equipment are the least provided in the educational institution. 


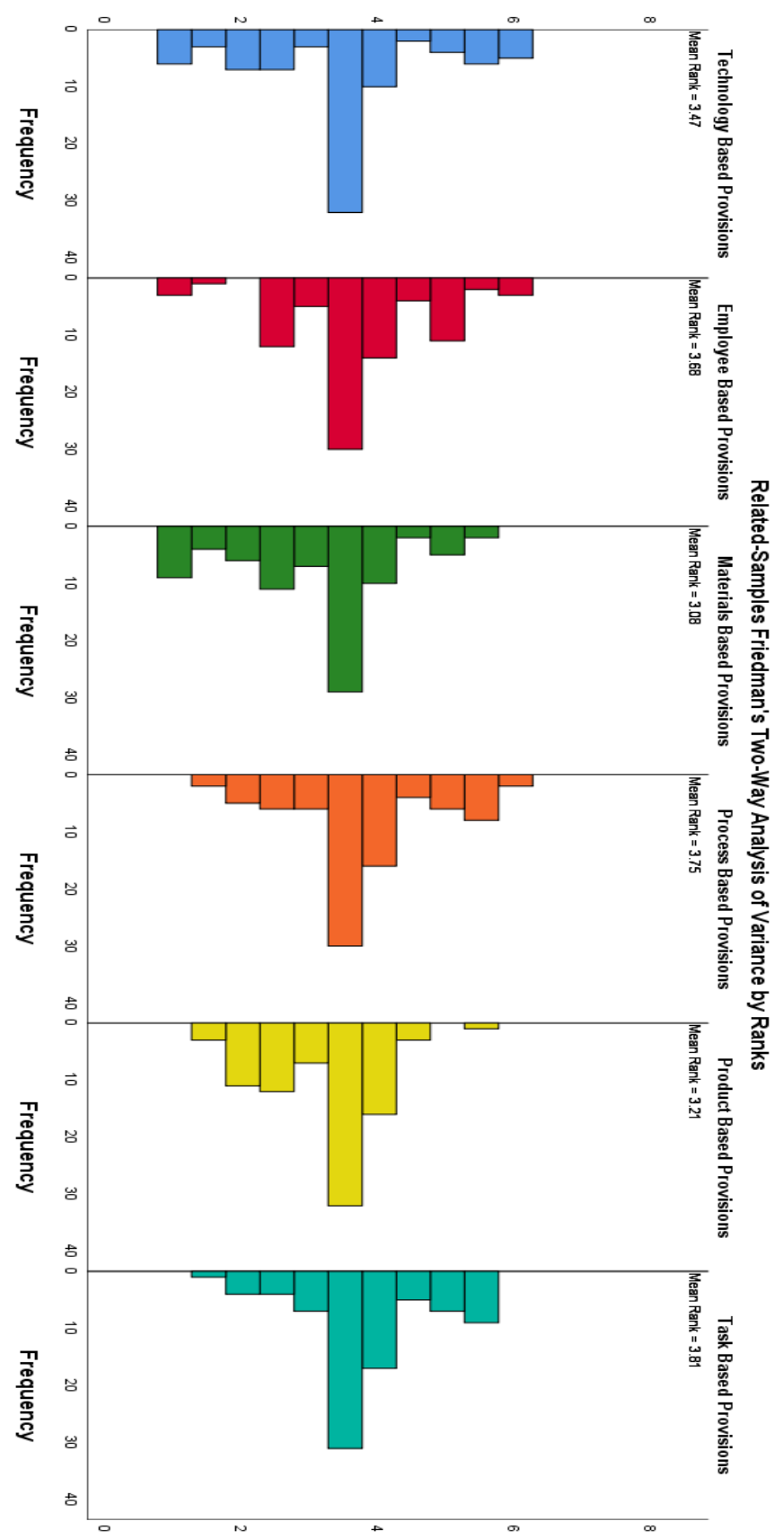

Figure 3: Mean ranks for productivity improvement techniques provision 


\section{Most Preferred Productivity Improvement Technique}

Based on Table 2, the result of the statistical tests applied states that there is a significant difference between the six (6) productivity improvement techniques' level of importance premised on the roles of the faculty employees.

Table 2: Hypothesis test summary for most preferred productivity improvement techniques

Hypothesis test summary

\begin{tabular}{l|c|c|c}
\multicolumn{1}{c|}{ Null Hypothesis } & Test & Sig. & Decision \\
\hline The distributions of Technology & Related-Samples & 0.013 & Reject the null \\
Based Importance, Employee & Friedman's Two-Way & & hypothesis. \\
$\begin{array}{l}\text { Based Importance, Materials Based } \\
\text { Importance, Process Based }\end{array}$ & $\begin{array}{c}\text { Analysis of Variance by } \\
\text { Importance, Product Based }\end{array}$ & & \\
$\begin{array}{l}\text { Importance and Task Based } \\
\text { Importance are the same. }\end{array}$ & & & \\
\hline
\end{tabular}

Based on the mean ranks, Figure 4 shows that most preferred and significantly important productivity improvement technique is Task-Based (Mean Rank $=3.65$ ), followed by Product-Based (Mean Rank $=3.55$ ) and Employee-Based (Mean Rank = 3.55), Process-Based (Mean Rank = 3.51), Materials-Based (Mean Rank = 3.41), and lastly, Technology-Based (Mean Rank =3.34). The findings implies that employees favor the continuous appreciation, motivation and encouragement from the management and the work culture itself. Rather than material and technology inputs that are readily available and accessible almost everywhere and can be purchased. A supportive management and positive feedback from them improves the employees performance based on their preference. 


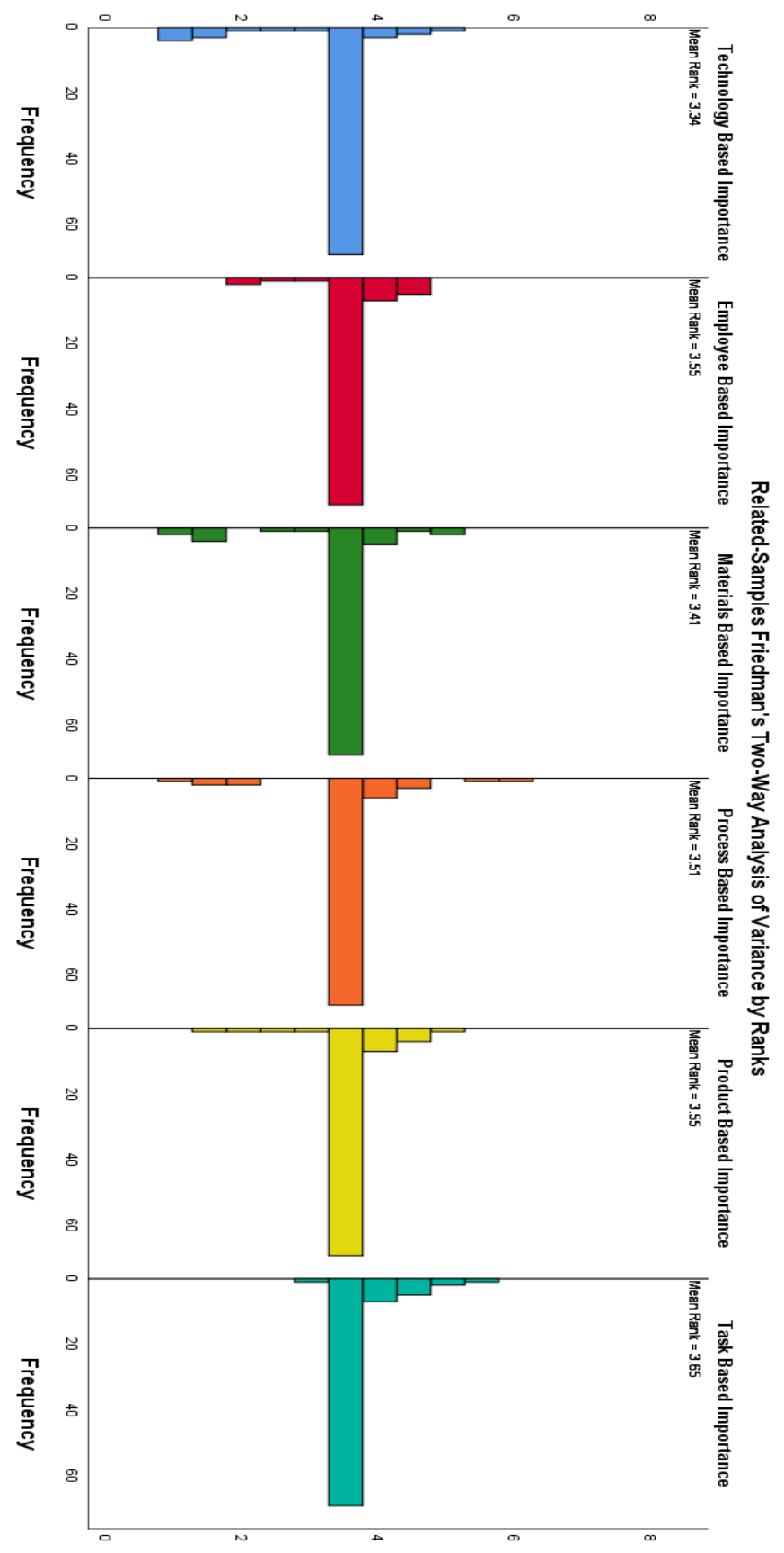

Figure 4: Mean ranks for productivity improvement techniques importance 


\section{Relationship between the Utilized and Preferred Productivity Improvement Technique}

Analyzing the data from the preceding section, it is clear that the most often used may not be the most significant. In order to draw conclusions, paired sample correlations are used to determine the strength of the relationship between the degree of provision and the level of importance of each productivity enhancement approach. These relationship is shown in Table 3. Whereas the technology-based productivity improvement technique provided is significantly correlated with its importance (Correlation $=0.362)$. Processbased $($ Correlation $=0.293)$, Task-based (Correlation $=0.263)$, Product-based $($ Correlation $=0.228)$, Employee-based (Correlation $=0.086)$, and Materials-based (Correlation $=0.051)$ follow. It is important to note that all of the matched samples show a positive correlation, indicating that there is a direct relationship between the level of provision and importance.

Table 3: Paired sample correlations for productivity improvement techniques Paired samples correlations

\begin{tabular}{|llr|r|} 
& & $\mathrm{N}$ & \multicolumn{1}{c|}{ Correlation } \\
\hline Pair 1 & $\begin{array}{l}\text { Technology Based Provisions \& } \\
\text { Technology Based Importance }\end{array}$ & 85 & 0.362 \\
\hline Pair 2 & $\begin{array}{l}\text { Employee Based Provisions \& } \\
\text { Employee Based Importance }\end{array}$ & 85 & 0.086 \\
\hline Pair 3 & $\begin{array}{l}\text { Materials Based Provisions \& } \\
\text { Materials Based Importance }\end{array}$ & 85 & 0.051 \\
\hline Pair 4 & $\begin{array}{l}\text { Process Based Provisions \& Process } \\
\text { Based Importance }\end{array}$ & 85 & 0.293 \\
\hline Pair 5 & $\begin{array}{l}\text { Product Based Provisions \& Product } \\
\text { Based Importance }\end{array}$ & 85 & 0.228 \\
\hline Pair 6 & $\begin{array}{l}\text { Task Based Provisions \& Task Based } \\
\text { Importance }\end{array}$ & & 0.263 \\
\hline
\end{tabular}

While correlation demonstrates that each paired sample has a positive relationship, the Paired sample T-test demonstrates how significantly the level of provision differs from the level of importance. According to the data in table 4, all paired samples are significantly different from one another. As a result, even if there is a positive relationship between the level of provision and the importance of each productivity improvement technique, there is still work to be done to increase its delivery to better fit the needs and preferences of each employee. 
Table 4: Paired sample test for productivity improvement techniques

Paired samples test

\begin{tabular}{|c|c|c|c|c|c|c|c|c|}
\hline & \multicolumn{5}{|c|}{ Paired Differences } & \multirow[b]{3}{*}{$\mathrm{t}$} & \multirow{3}{*}{$\begin{array}{l}\text { Sig. }(2- \\
\text { tailed })\end{array}$} \\
\hline & & \multirow{2}{*}{$\begin{array}{c}\text { Mea } \\
\mathrm{n}\end{array}$} & \multirow{2}{*}{$\begin{array}{l}\text { Std. } \\
\text { Deviati } \\
\text { on }\end{array}$} & \multirow{2}{*}{$\begin{array}{l}\text { Std. } \\
\text { Error } \\
\text { Mean }\end{array}$} & \multicolumn{2}{|c|}{$\begin{array}{l}\text { 95\% Confidence } \\
\text { Interval of the } \\
\text { Difference }\end{array}$} & & \\
\hline & & & & & Lower & Upper & & \\
\hline $\begin{array}{l}\text { Pai } \\
\text { r } 1\end{array}$ & $\begin{array}{l}\text { Technology Based } \\
\text { Provisions - Technology } \\
\text { Based Importance }\end{array}$ & $\begin{array}{r}- \\
.447\end{array}$ & .646 & .070 & -.586 & -.308 & $\begin{array}{r}- \\
6.38 \\
4\end{array}$ & 0.000 \\
\hline $\begin{array}{l}\text { Pai } \\
\text { r } 2\end{array}$ & $\begin{array}{l}\text { Employee Based } \\
\text { Provisions - Employee } \\
\text { Based Importance }\end{array}$ & $\begin{array}{r}- \\
.459\end{array}$ & .733 & .079 & -.617 & -.301 & $\begin{array}{r}- \\
5.77 \\
3\end{array}$ & 0.000 \\
\hline $\begin{array}{l}\text { Pai } \\
\text { r } 3\end{array}$ & $\begin{array}{l}\text { Materials Based } \\
\text { Provisions - Materials } \\
\text { Based Importance }\end{array}$ & $\begin{array}{r}- \\
.624\end{array}$ & .801 & .087 & -.796 & -.451 & $\begin{array}{r}- \\
7.17 \\
3\end{array}$ & 0.000 \\
\hline & $\begin{array}{l}\text { Process Based Provisions - } \\
\text { Process Based Importance }\end{array}$ & $\begin{array}{r}- \\
.400\end{array}$ & .621 & .067 & -.534 & -.266 & $\begin{array}{r}- \\
5.93 \\
8\end{array}$ & 0.000 \\
\hline $\begin{array}{l}\text { Pai } \\
\text { r } 5\end{array}$ & $\begin{array}{l}\text { Product Based Provisions - } \\
\text { Product Based Importance }\end{array}$ & $\begin{array}{r}- \\
.624\end{array}$ & .690 & .075 & -.772 & -.475 & $\begin{array}{r}- \\
8.33 \\
6\end{array}$ & 0.000 \\
\hline $\begin{array}{l}\text { Pai } \\
\text { r } 6\end{array}$ & $\begin{array}{l}\text { Task Based Provisions - } \\
\text { Task Based Importance }\end{array}$ & $\begin{array}{r}- \\
.459\end{array}$ & .665 & .072 & -.602 & -.315 & $\begin{array}{r}- \\
6.36 \\
5\end{array}$ & 0.000 \\
\hline
\end{tabular}

\section{Specific Provisions for Productivity Improvement}

The impact of using productivity improvement techniques on a faculty's performance in each of their given responsibilities may be observed through the output they accomplish. A faculty that has a good supply of the necessary productivity enhancement strategies may function efficiently and effectively. While a faculty with a dearth of much-needed productivity development strategies may struggle to carry out their given duties and obligations. The most common duties of a faculty employee includes but is not limited to: Facilitating Instruction, Other assigned works such as Accreditation, Conducting Research, Pursuing Professional Development and Participating in Extension Programs.

Employees were asked what productivity resources and supplies they needed to increase their performance and academic output. The majority of their responses are Employee-Based Productivity Improvement Techniques, such as pay, health insurance, training support, research, and graduate studies. Employees also desired to be involved 
in policy implementation. Others proposed a task-based strategy, which includes incentive to provide excellent education to every student as well as being a part of policy development and execution, which is a component of a successful management style. They are also recommending reference materials for the improvement of instruction, research and other assigned works. Furthermore, giving employees free rein on effective time management on job completion allows them to use their full potentials to fulfill their tasks within given deadlines. These specific provisions desired by the employees can be traced on the most preferred productivity improvement technique and those with least correlations.

\section{Conclusion}

Employee productivity is a crucial component in the success of an organization. A strong, efficient workforce is critical to the success of any business. That is why investing time, money and resources on faculty employee productivity makes sense. Ensuring that the proper atmosphere is created and that the organization's processes and values are successfully executed to promote work satisfaction. This, in turn, will have a beneficial influence on the workers' commitment and productivity for the organization.

Results showed that the task-based productivity improvement technique is the most commonly employed by management and the most preferred by faculty. This expresses the idea that the organization's management encourages an effective management style, develops a positive work atmosphere, and motivates employees to perform their best in their assigned roles. Employees, on the other hand, prefer that management publicly display praise, constructive criticism, achievement, and encouragement in order to boost their productivity. Employees are understandably motivated to achieve more and better when they believe they are encouraged and supported by management.

While both task-based productivity improvement techniques are widely used and valued, they do not have the highest positive correlation. The provisions and relevance of technology-based productivity improvement techniques are likely to meet the provisions and importance in the current conditions. The academic work is being dramatically redefined as a result of the emergence of a new age of teaching and learning. Most educational institutions are increasingly using the potential of digital technology, with one example being a school's online learning management system platform, which is used to distribute content and conduct assessments digitally. In this case, Holy Cross College prides itself with an Online Learning Management system that is being utilized for an efficient facilitation of instruction. Management information system were also being strengthened to further provide platforms for other assigned works.

The findings also indicate a strong need for employee-based and material-based 
productivity improvement technique as these two have the least positive relationship between the level of provision and importance. Employees need to be developed in skills, knowledge and attitude so that their work may also develop productively. Employees equipped with professional training and development can make contingent responses to changes in the education system, societal expectations and their assigned works. They would be more willing to facilitate instruction, do other assigned works, conduct researches and participate in extension programs if the faculty are receiving financial and non-financial incentives, employee promotion and improved job design, job enlargement, job enrichment. Tangible inputs are also significant in determining teacher output. It would be difficult to conduct instruction and research without the necessary reference resources. Employees would be unable to create the necessary output, such as paperwork and reports, unless they had access to the necessary classroom and office materials.

Based on the conclusions, this study believes that the necessary strategies for improving productivity will be implemented thoroughly. Progressive use of improvement approaches in productivity should minimize production waste and enhance the moral of faculty, as the provisions of the administration of the institution have a direct visible influence. In addition, further improvements may be achieved through cooperation with other higher education and organizational institutions in the research of productivity development approaches in education.

\section{References}

Bandyopadhyay, J. K., \& Lichtman, R. (2007). Six Sigma approach to quality and productivity improvement in an institution for higher education in the United States. International Journal of Management, 24(4), 802.

Bisson, B. (2021, August 25). 8 ways to increase productivity in the workplace. Business Town. Retrieved September 14, 2021, from https://businesstown.com/8-ways-increase-productivity-workplace/.

Boel, B. (2003). The European Productivity agency and transatlantic Relations: 19531961. Museum Tusculanum Press.

DeLorenzo, R., Johnson, J., \& Dykes, G. (2011). Productivity in Education. https://doi.org/http://www.effdebate.org/wpcontent/uploads/2014/06/productivity-in-education.pdf

Duby, J. J. (1994). Industry productivity improvement techniques for education: A reverse technology transfer? Nato Asi Series F Computer and Systems Sciences, 135, 9-9.

Duran, C., Cetindere, A., \& Aksu, Y. E. (2015). Productivity improvement by work and time study technique for earth energy-glass manufacturing company. Procedia Economics and Finance, 26, 109-113.

Hanushek, E. A., \& Ettema, E. (2017). Defining productivity in education: Issues and illustrations. The American Economist, 62(2), 165-183. https://doi.org/10.1177/0569434516688207 
Hawkins, L., \& Knowledge, P. (2001). Fundamental Productivity Improvement Tools and Techniques for SME. Loughborough, Pera Knowledge, (33).

Hilgert, R. L. (1964). Modern organization theory and business management thought. American Behavioral Scientist, 8(2), 25-29.

Kumar, S. A., \& Suresh, N. (2008). Production and operations management (with skill development, caselets and cases). New Age International (P) Ltd., Publishers.

Learning and teaching materials. Learning and teaching materials | Unesco IIEP Learning Portal. (n.d.). Retrieved September 14, 2021, from https://learningportal.iiep.unesco.org/en/issue-briefs/improve-learning/learningand-teaching-materials.

Lunenburg, F. C. (2011). Goal-setting theory of motivation. International Journal of Management, Business, and Administration, 15(1), 1-6.

Mason, R. O. (1979). A general systems theory of productivity. International Journal of General System, 5(1), 17-30.

News. IspatGuru. (n.d.). Retrieved September 18, 2021, from https://www.ispatguru.com/employee-productivity-and-its-influencing-factors/.

Pokhrel, S., \& Chhetri, R. (2021). A literature review on impact of covid-19 pandemic on teaching and learning. Higher Education for the Future, 8(1), 133-141. https://doi.org/10.1177/2347631120983481

Santos, J. V., \& Gallardo, D. L. (2021). Ergonomic hazards in the workplace: Assessment, evaluation and prevention in the educational environment of Holy Cross College. International Journal of Multidisciplinary Research and Analysis, 04(07). https://doi.org/10.47191/ijmra/v4-i7-11

Santos, J. V. L. (2021). Contingency Theories of Leadership: Effectiveness of the College Instructor's Leadership Style. Educatio: Journal of Education, 6(2), 107-113.

Subia, E. G. S., Jocson, E. J. C., \& Florencondia, E. N. T. (2019). Flood prevention and mitigation initiatives towards a flood-free city. American Scientific Research Journal for Engineering, Technology, and Sciences (ASRJETS), 58(1), 215-224.

Use of technology in teaching and learning. Use of Technology in Teaching and Learning | U.S. Department of Education. (n.d.). https://www.ed.gov/oiinews/use-technology-teaching-and-learning.

Yoshifumi, H., Sammogram, S., \& Manzuma-Nd, N. M. (2017). Effect of productivity and perceived quality on organizational performance from lean management practice perspective. Research Journal of Business Management, 12(1), 1-9. https://doi.org/10.3923/rjbm.2018.1.9

5 critical factors Affecting employee productivity at WORK - Sage HR Blog. Sage HR Blog | Easy to implement HR tips! Retrieved on September 12, 2021 from https://blog.sage.hr/5-critical-factors-affecting-employee-productivity-at-work/. 